$J-6-4$

粷科治療注視置の考案と応用

吉嗣 國男 ○中島 幸一

( 福岡米科大学口腔衛生学教室)

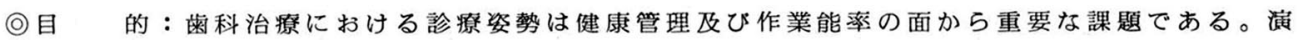
者らは歯科診療時における術者の動的姿勢の把握ならびに診療能率の適確性を進めるために種々 検討を加えてきた。

1. 診療姿勢の再現性

2. 口腔内, 部位別チェックの難易度

3. 菌牙の中央部の表面および深部の位置のチェックの巧緻度

4. 初心者の訓練用

以上を目標に, 菌科治療注視装置 (Dent Practical Checker 以下 D P C と略す) 考按し, 更 に検討を加え，図1写真 2 に示すような装置とした。これは患者の口腔シュミレーションとして Dental Study Model の中の被検茵に対し表面及び深部いわゆる根管部に分け，それぞれI型， II 型とし, 図4のように改良した。今回は主に I 型の装置を使い, 初心者(菌科学生)を対象とし, 難易度の判定及び訓練用としてフィールド実験を行った。

D.P.C I 型の特徵は

A. 菌とハンドピースの位置, 角度の設定がデジタルコンパレーターにて簡単にできる。

B. 正反応時にはブザーにてフィードパックができる。

C. 正反応時と N G 回数が同時に測定できる。

D. 反応曲線はレコーダーにてキャッチできる。

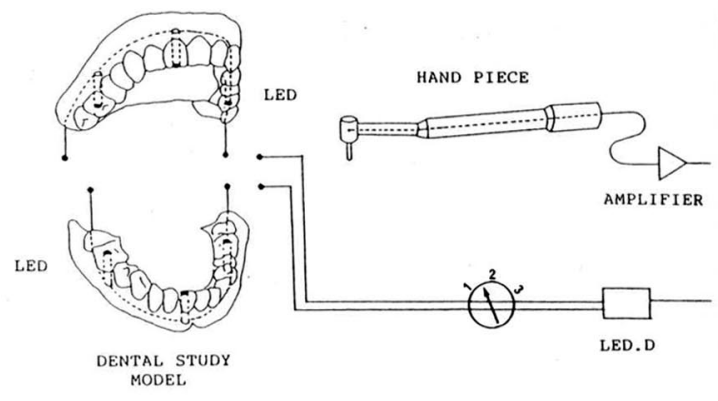

Fig. 1. SCHEMA OF DENT PRACTICAL CHBCKER

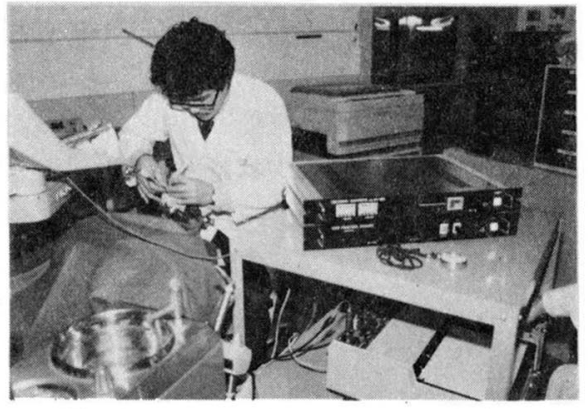

Fig. 2. Practice of Dent Practical Croker

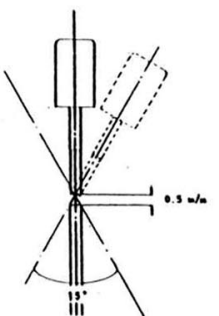

Fig. 3. Schema of Working Capacity

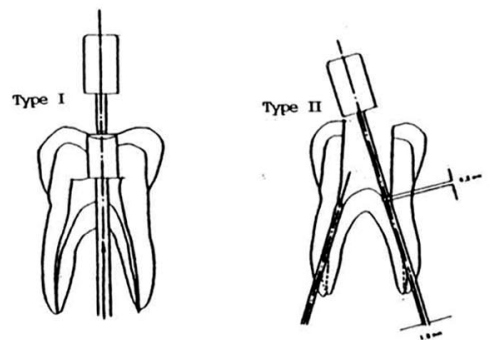

Fig. 4. Schema of Dent Practical Checker Type I \& II 
○方 法：D. P. C. の設定条件として下記のようにした。

$\begin{array}{lr}\text { Low value } & 100.0 \\ \text { High value } & 199.9 \\ \text { Opened distance } & 50.0(\mathrm{~m} / \mathrm{m}) \\ \text { Working distance } & 0.5--1.0(\mathrm{~m} / \mathrm{m}) \\ \text { Working time } & 10.0 \text { ( } \mathrm{sec}) / \text { tooth } \\ \text { Stabilization } & : \text { one finger fixation }\end{array}$

被検者の座位の位置は12時（頭側）位をとった。各被検者の利き手にハンドピースを握り、他方の手 にデンタルミラーを持って、通常の診療のポシションをとり、「ヨーイ、はじめ」で開始し、10秒間 のうちにロ腔内にハンドピースとデンタルラーをいれて、正指向をねらう。設定条件の範囲内に八 ンドピースがはいると、被検者はフィードバック音を目安に、位置・角度を一定に維持固定する。

今回の報告では、一連の試験行程を10秒間に設定して、正指向の時間と設定簕囲をはずれた回数 （NG）とを测定した。以上の作業を5回行って、1 回分のテストを終え、約 3 分間休けいをとると いうパターンで、5回分を1クールとして、データをとった。

また、いずれの実験行程す、設定条件以下の正指向で、フィードバック音がならない場合です、正 指向の程度をモニターするために、レコーダに記録をとった。

\section{（結果おょび 考察}

全体の傾向としては、上䫑の正指向時間よりあ、下䫑の正指向時間の方が長かった。また、N $\mathrm{G}$ 回 数す少なかった。てれは、下顎の方が狙っているポイントを直視できるが、上額の方はデンタルミラ 一に映った像をみながら、操作をするためのあのと考えられる。

また、左右差では、利き手（今回は右手）の側（右側）の方が、反対側よりあ正指向時間が長かっ た。また、N G 回数も少なかった。てれは、いわゆるデンタルミラーテクニックが充分に修得されて いない上に、デンタルミラーの支持柄でスタディモデルの䝷部ラバーを圧排するととが難しいためと 考えられる。個々のケースに関しては、いずれも訓練回数を重ねてゅくと、正指向時間す長くなり、 N G 回数も減少するが、その上限・下限に関しては今後の追試を要する。 